\title{
Cultura e Política nos Quadrinhos de Henfil
}

\author{
Maria da Conceição Francisca Pires*
}

\begin{abstract}
Resumo:
O artigo apresenta uma incursão pelo universo discursivo dos polêmicos personagens "Fradins", criados pelo cartunista Henfil. A intenção é colocar em relevo a construção de uma crítica política e de costumes que colocou em xeque, por um lado, o cristianismo oficioso das elites políticas e religiosas e, por outro, os simulacros sociais. No caso em questão não se trata apenas da crítica à devoção, mas especificamente a devoção ao poder. Defendo a premissa de que por intermédio do grotesco e do fantástico, em conjunto com a ironia e a carnavalização, Henfil desmistificou as deidades políticas e religiosas, substituindo-as pela dúvida e colocando-as lado a lado com o ridículo. Deste modo, o humor henfiliano representou um esforço de resistência, ao mesmo tempo em que contribuiu para a luta política contra a ditadura militar.
\end{abstract}

Palavras-chave: humor, política, ditadura.

Durante os anos de intensificação da coerção e da censura sobre os agentes e produtores de cultura no Brasil, a imprensa alternativa se destacou pela desabrida opção de rejeitar o papel que a grande mídia vinha desempenhando desde a conflagração do golpe em 64. Gradativamente, esta se transformou num dos principais veículos utilizados por diversos atores sociais para expressar a oposição ao regime instaurado e ao modelo econômico proposto, a defesa da restituição do respeito aos direitos humanos e de transformações sociopolíticas que restaurassem o espaço para atuação política das massas e de seus representantes legais e legítimos.

No interior da imprensa alternativa destaca-se a atuação do cartunista Henfil no jornal Pasquim, expressando, através de suas histórias em quadrinhos, uma postura combativa e irreverente contra o autoritarismo no âmbito político e dos costumes e o moralismo das classes médias. $\mathrm{O}$ trabalho desenvolvido por Henfil em conjunto com o grupo do Pasquim mostrou-se relevante não só porque foi a partir desta associação que sua carreira ganhou um impulso diferenciado, pois se sabe que foi sobretudo após a publicação dos seus desenhos naquele jornal que estes ganharam respaldo nacional. Mas também porque foi durante sua trajetória no Pasquim que se apuraram os traços 
daqueles que seriam os seus personagens mais marcantes: os Fradins, assumindo uma conotação mais anárquica e sádica fundamental para defrontar-se de forma direta com os dogmas, medos e repressões derivados dos virtuosismos religiosos, morais e políticos.

No Pasquim Henfil encontrou espaço para conflagrar de forma mais aberta sua armada tanto contra as práticas políticas e econômicas do regime, como jornalísticas e comportamentais vigentes, influenciando, de maneira sui generis, a organização dos diferentes atores sociais para a participação e organização das demandas democráticas na vida política brasileira. Foi no interior do jornal e das redes sociais ali existentes que o seu discurso denunciatório foi gerado, ganhando forma e sentido, constituindo um local formador de redes de sociabilidades, fundamental para a interpenetração de idéias entre os colaboradores, seus críticos, interlocutores e leitores.

As redes de sociabilidades desenvolvidas entre o grupo do Pasquim, aqui incluído Henfil, ao mesmo tempo em que estabelecem práticas que revigoram sentimentos coletivos, propiciam a afirmação de valores e atuam para construir identidades, fazem parte de relações de poder em que se competem por elementos de ordem simbólica como status, prestígio, posições de inferioridade ou superioridade e contribuem para que se acentue a afirmação das diferenças (Rezende, 2001, p.1). Assim, ao lado dos elementos de aproximação entre o grupo existiram elementos de conflito que atuaram de forma fundamental para a definição das identidades e das diferenças dos mesmos.

Trata-se da junção de atores sociais que vinham de lugares e de pólos de produção cultural distintos. No caso de Henfil, cujas bases discursivas parecem estar profundamente marcadas pelos movimentos de esquerda pré-64, sob influência do Centro Popular de Cultura - $\mathrm{CPC}^{1}$, há uma visível preocupação em fazer do seu humor um instrumento de crítica social e política. Mesmo quando participava de jornais com caráter exclusivamente esportivos, como o carioca Jornal dos Sports, não se abstinha de injetar uma boa dose de humor político em seu interior através dos personagens voltados para a representação dos torcedores dos times de futebol.

Urubu numa referência aos torcedores do Flamengo, Bacalhau, fazendo alusão à ascendência portuguesa do time do Vasco, Pó de Arroz, numa menção ao alto padrão social da torcida do Fluminense, a denominação Cri-Cri para os torcedores do 
Botafogo, acusados pelas torcidas rivais de excessivamente implicantes, e a alcunha de Gato Pingado para o pequeno número de torcedores do América (Moraes, 1996).

Segundo Henfil, "eu queria relacionar o futebol à realidade social, jogar com o perfil dos torcedores. Dentro dessa espécie de luta de classes, eu fazia histórias paralelas ao mundo do futebol. Era uma maneira de passar alguma coisa crítica naquela época de censura" (ibidem, p.78 e 97). Nessa passagem pela imprensa esportiva destaca-se a recepção do público aos seus personagens expressa através de cartas enviadas ao jornal ou de manifestações públicas que referendavam tais caracterizações ${ }^{2}$. Mas, conforme consta em alguns dos seus relatos e na biografia produzida por Moraes, as motivações que o levavam a se manter neste tipo de publicação eram exclusivamente financeiras, sem que houvesse uma afinidade temática e de propósitos.

Estes últimos aspectos, afinidade temática e de propósitos, são facilmente identificáveis no Pasquim, o que não diminuiu o tom hesitante de sua resposta: "Olha, eu não sou de Ipanema...", ao convite de Sérgio Cabral que, como Jaguar, acreditava que o tipo de humor produzido por Henfil, "humor porrada", se ajustava como uma luva ao perfil do Pasquim (Moraes, 1996, p.100). Acredito que tal resposta expressa a significativa distância simbólica entre o lugar social que matizou sua produção intelectual e as referências associadas à patota do Pasquim.

Henfil chegara ao Rio de Janeiro em setembro de 1967, após aceitar, também de forma receosa, o convite da diretoria da sucursal do Rio do Jornal dos Sports (JS) para ilustrar os anúncios do jornal $O$ Sol que viria encartado no JS. Até então, vivera em Belo Horizonte galgando sua promissora trajetória profissional através de participações nos jornais e revistas locais como Alterosa, Diário da Tarde, Última Hora, Diário de Minas e o Jornal dos Sports (MG), e começara, também naquele momento, a aprofundar um relacionamento amoroso com Gilda Cosenza.

De origem familiar modesta, desenvolveu sua formação individual e política naquilo que ele chamava de "complexo hospitalar-favelado", situado no bairro de Santa Efigênia, periferia de Belo Horizonte. Essa vivência comunitária, que ele buscava reforçar ao afirmar: "sou fiel ao útero onde cresci e de onde trouxe as marcas do que sou hoje", não só lhe ofereceu intimidade com um universo misto de pobreza, solidariedade e morte, como aprofundou sua preocupação com as questões ligadas à política e aos problemas sociais. No que tange as discussões políticas e culturais que circulavam naquele momento, bem como sobre a função social dos artistas e intelectuais, destaca-se sua preocupação em colocar em evidência uma postura singularmente crítica, pois, em 
sua concepção, seu trabalho fazia parte da luta política contra a ditadura: "eu tô fazendo história em quadrinhos porque eu tenho uma coisa que não é só minha, é luta de muita gente" 3 . Foi a defesa acirrada de tal premissa que o envolveu numa ampla rede de discordâncias que mais tarde foram interiorizadas em alguns de seus desenhos.

A série intitulada Comitê de Caça aos Carecas $-\mathrm{CCC}^{4}$, uma referência explícita ao Comando de Caça aos Comunistas, inaugurou essa linha de ação crítica.

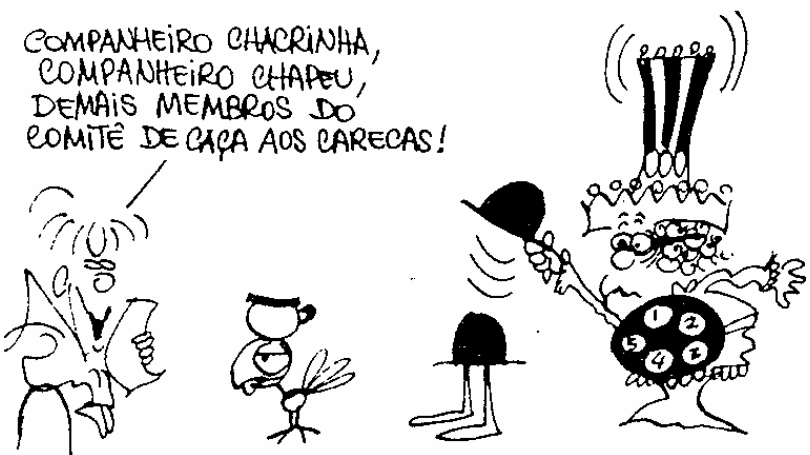

Figura 01 - Fonte: Jornal Pasquim
Tratava-se de um grupo liderado pelo Baixim com o acompanhamento de outros três personagens: $\quad$ o apresentador Chacrinha, o personagem Chapéu e o papagaio Pô de Souza, cujo instrumento utilizado para rastrear os carecas - segundo o cartunista, pessoas geralmente "alienadas, consumistas e de caráter duvidoso" - era um penico.

Os apresentadores Flávio Cavalcanti e Carlos Imperial e o cantor Wilson Simonal foram os primeiros a ser alçados por essa principiante jornada justiceira via humor.

Na mesma tendência crítica foi criado em 1971 o Tamanduá, "a besta do apocalipse que assola nosso torrão", aquele que "chupa cérebros para revelar as faces ocultas de pessoas que aceitam as condições políticas e culturais vigentes”. Mas é no número 129, do final do ano de 1971, que se encontra o anúncio daquele que seria o mais polêmico dos seus instrumentos de derrisão dos seus adversários políticos e intelectuais: o Cabôco Mamadô, protagonista do Cemitério dos Mortos-Vivos 5 . Segundo Zuenir Ventura, citado por Moraes, o cemitério traduzia: 
Um desesperado, às vezes injusto e extremado gesto de conclamação à resistência democrática. ... Hoje a minha leitura daquele sectarismo aparente de Henfil leva-me a crer que o Cemitério dos Mortos-Vivos embutia uma metáfora: quem não está lutando e resistindo está morrendo ou já morreu. Ele ressaltava essa morte simbólica e nos dizia: precisamos resistir de alguma maneira. (Moraes, 1996, p.134)

Não pretendo expor detidamente todos aqueles que foram enterrados naquele cemitério, uma vez que a lista é extensa demais; neste momento me interessa apenas destacar o amplo debate que tais desenhos proporcionaram não só sobre as motivações de cada enterro, mas também sobre a forma cruel utilizada pelo cartunista para expressar o descontentamento com tais posturas políticas, incitando seus pares à reflexão.

No que tange à sua vida pessoal, sobressai-se, também, o engajamento político expresso nas participações contínuas em campanhas e projetos civis que discutiam os problemas nacionais trazidos pela repressão militar.

Tais temas estavam também no cerne dos desenhos e textos dos demais colaboradores do Pasquim ${ }^{6}$. Entretanto, em geral, colocava-se às claras a proximidade destes com o universo zona sul carioca, onde, inclusive, se estabelecera a sede do jornal, e o direcionamento para um público consciente de sua participação na sociedade burguesa, composto por intelectuais e estudantes de classe média, retratados por Henfil como sendo:

... de moda, muda de filósofo, de Marcuse, como quem muda de camisa. Muda de cantor, como quem muda de cueca. Fica mudando porque não tem raiz nenhuma - devido à formação estrangeira, vive de costas para o Brasil. O sonho deles é pegar uma bolsa de estudos para a Europa, é ir passear ou trabalhar nos Estados Unidos. (ibidem, p.109)

A preocupação em se apresentar como representantes deste espírito carioca, em geral associado à boêmia, à Ipanema e ao jeito malandro de conduzir a própria empresa jornalística, fora colocada em evidência de várias formas: em chamadas do tipo "Pasquim - um ponto de vista carioca", através dos artigos de Luiz Carlos Maciel, cujo título, "Cultura de Verão", tentava pôr o leitor a par das discussões que se desenrolavam "naquele ponto da praia de Ipanema que ficava em frente à Rua Montenegro (hoje chamada de Vinicius de Moraes), onde se reuniam os que eram interessados em cultura 
e pretendiam estar "sabendo das coisas"” (Rego, 1996, p.35), ou nas "Dicas" onde em geral eram comentados trabalhos relacionados à cena artística e cultural carioca.

Segundo Henfil, "a equipe inicial do Pasquim era muito intelectualizada ...", e sua inserção no grupo, trazendo consigo os Fradinhos "fazendo xixi, cocô, dando peido e aquelas coisas", no contexto de suspensão vivido em função do acirramento da repressão, colaborou de forma significativa para a catarse do Pasquim, impedindo que este se transformasse na "revista Senhor de novo, que é o que eles queriam fazer!" (Souza, 1984).

Em comum com a equipe já constituída do jornal, e talvez seja esse um dos elementos de mediação entre eles, tem-se uma forma singular de engajamento sem estabelecer conexões objetivas com uma militância do tipo panfletária, representando um ativismo dissociado de uma fidelidade ideológica, bem como a ausência de moderação do tom de suas falas ao expressar a desconfiança "em relação aos discursos fechados e simbólicos das certezas, verdades e palavras de ordem" (Hollanda, 1992, p.35), característicos da esquerda revolucionária, sobretudo do Partido Comunista. Some-se a isso a crítica afiada aos conceitos e tabus estabelecidos pelo moralismo burguês católico, o fechamento dos circuitos de publicação e a impreterível necessidade de criar meios alternativos de manifestação, crítica e de protesto contra a ditadura militar, e acredito que tenha conseguido reunir os elementos centrais para manutenção do equilíbrio entre os contrastes existentes no interior do grupo.

\section{- Top!Top! : a inocência pagã dos Fradins}

Em 25 de julho de 1964 foi publicada na revista Alterosa a primeira estória dos Fradins. Conforme depoimento de Henfil, a criação dos dois personagens foi uma imposição do editor da revista, Roberto Drumond ${ }^{7}$. O vínculo entre os personagens Baixim e Cumprido remete às "matrizes clássicas do humor, através do par contrastante e compensatório de carências recíprocas (o Gordo e o Magro, Oscarito e Grande Otelo, ... e, bem anteriores, Dom Quixote e Sancho Pança, dentre outros)" (Silva, 2000, p.19), constituindo uma relação dialética que interpreta a realidade a partir dessa vivência complementar entre os opostos.

Quando observados com um pouco mais de atenção, identifica-se nos Fradins um auto-retrato do autor. Segundo Henfil, era "na boca dos fradins" que ele colocava a 
sua "divisão interna. Então metade do meu comportamento era como Cumprido e

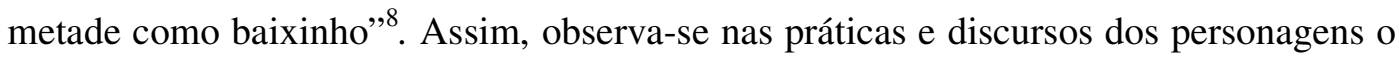
conflito íntimo do autor entre dois universos distintos e complementares: entre a religiosidade repleta de mitos, que o torturou até a adolescência, e a religião politizada apresentada pelos dominicanos; entre se dedicar à sociologia ou à atividade de chargista, tendo um desenho "fraco e sem um mercado de trabalho que suportasse um humorista profissional" ${ }^{9}$; entre a insistência em se manter livre de partidarismos e a atuação como intelectual engajado.

Em várias estórias, traços de sua identidade (origem, idade, fetiches sexuais, etc. - Silva, 2000) foram incorporados pelo personagem Baixim. As mais freqüentes foram as referências à sua formação religiosa e a paixão por pés femininos. Aliás, a atração por pés femininos foi um traço marcante também da personalidade do bode Orelana, do Alto da Caatinga.

Os Fradins representaram também uma forma simbólica de participação na luta política apesar dos limites físicos impostos pela hemofilia. Henfil garantia ter "uma certa intuição de que uma limitação física ou mental ou social ativa ..., abre o apetite para que você saia criando alternativas fora de você" (Seixas, 1980, p.154-8). Desse modo, estes personagens realizaram a tarefa de executar as diferentes alternativas de vida criadas por ele, mas impossíveis de ser vivenciadas dada a limitação física imposta pela hemofilia.

Como parte desse caráter autobiográfico encontram-se no seu desenho alusões às experimentações vivenciadas próximas às favelas em Belo Horizonte, onde o autor residiu em grande parte de sua infância, que não caracterizava especificamente as vivências e os valores da classe média, embora também fossem comuns a esta.

Conforme seu depoimento, a vivência no bairro de Santa Efigênia foi fundamental para sua formação e para a caracterização de sua produção humorística, pois o fez conhecer a diversidade no interior da miséria. Naquele bairro entrecruzavamse:

Uma pensão de tuberculosos, o maior sanatório brasileiro, um asilo de velhos, a agência funerária, a casa do pequeno jornaleiro, o campo do América Futebol Clube, a Santa Casa de Misericórdia que era imensa, e para onde vinham todos os migrantes. Vinham do Nordeste, passavam por Belo Horizonte, adoeciam na viagem, morriam ou não agüentavam continuar e ficavam ali na porta da Santa casa esperando internamento. ... . Tinha o Hospital São Lucas, Hospital da lepra, Hospital do Câncer, Chagas, Faculdade de Medicina onde brincava, às vezes, 
vendo cadáveres sendo dissecados, aquelas coisas. O rio Arrudas que é o rio descarga de Belo Horizonte, onde eu brincava. Duas favelas: a Dos Urubus e Pau-Comeu; um matadouro. Isso tudo colado, um do lado do outro. ... Foi o maior curso de sociologia que fiz. Não estudei o subdesenvolvimento com o Celso Furtado na universidade, eu o vi pessoalmente. ${ }^{10}$

Associada a estas experimentações infantis estava a realidade brasileira contemporânea, o cotidiano das classes médias e baixas das grandes cidades que o autor insistia em manter próximo ao seu trabalho, uma vez que acreditava ser esta proximidade fundamental para conquistar a anuência popular para o seu trabalho. No ambiente plural vivido durante a infância Henfil conquistou significativa intimidade com o sadismo explícito e inocente vivenciado nas brincadeiras infantis, onde nem doenças graves como a própria hemofilia eram poupadas ${ }^{11}$.

Na primeira edição do Almanaque dos Fradinhos, um tablóide publicado em 1971 onde constam os primeiros trabalhos publicados no Pasquim, consta a publicação de uma laudatória carta à sua mãe, D. Maria, destacando a importância da rigorosa educação católica recebida tanto para a composição dos Fradins, como para o êxito profissional do cartunista.

A primeira estória dos Fradins, publicada na revista Alterosa, se constituiu de cinco quadros onde os dois frades atuam em conjunto jogando contra os transeuntes frutos colhidos da árvore em que estão escondidos. Nesta não se identifica "oposição entre Baixim e Cumprido e sim entre ambos e os outros", mas é notória a introdução da “metáfora do poder militar" (Silva, 2000, p.80). Por outro lado, destaca-se, desde então, provavelmente sob a inspiração dos bonecos silenciosos do cartunista mineiro Mauro Borja Lopes (Borjalo), os traços lacônicos e ausência de um colóquio verbal entre os atores, que se comunicam através de gestos, bem como a não identificação dos personagens. $^{12}$

Com o fechamento da revista no final do mesmo ano, os dois personagens tiveram breves aparições no Diário de Minas (entre 1966-1968) e no jornal O Paiz (final de 1968). Neste momento já se observam alterações significativas na configuração dos desenhos, que começam a assumir as feições que vão lhes caracterizar no Pasquim. Neste jornal a primeira apresentação dos dois frades se deu no número 2, em julho de 1969, ocupando apenas um quarto da página 06. Pouco tempo depois estes se tornaram uma das principais atrações do jornal, sendo destaque nas chamadas de capa e 
interagindo, em vários momentos, com o rato Sig, personagem de Jaguar e protagonista do jornal.

Nas estórias apresentadas destaca-se o amadurecimento do aspecto gráfico, no que tange a redução dos traços dos dois personagens. Também o cenário se restringe, ficando circunscrito às duas pedras onde os dois frades sentam e interagem; a preocupação com a ambientação será retomada posteriormente na revista Fradim, quando o autor dispõe de maior espaço para desenvolver as estórias. Outro aspecto que se evidencia é o aprimoramento dos traços psicológicos dos personagens associados à tensão entre os dois, definindo o "Cumprido como mais convencional em relação aos valores dominantes e o Baixim como desafiador e moleque” (Silva, 2000, p.81). Entretanto, no que tange à diferença entre os personagens, tal oposição freqüentemente assumiu um caráter de complementaridade, pois a fragmentação das certezas de um e outro ocorre mais para desmistificar tal argumentação do que especificamente para negá-la. A discordância não conduz ao abandono dos seus ideários e argumentos, mas ao desmonte da superficialidade dos mesmos, o que faz o mote da estória ser esta encenação dos contrários.

Finalmente, é a partir deste momento que se identifica a diminuição das sutilezas discursivas, havendo maior interação entre os personagens e o leitor, através da adoção do discurso direto.

Embora Henfil publicasse seus desenhos em outros jornais e revistas, como o Jornal do Brasil e nas revistas Placar e Isto É, foi por intermédio do Pasquim, cujo alcance transcendia o território ipanemense, que ele conseguiu ampliar sua rede de influências e divulgar sua produção mais livremente, apesar dos rigores da censura sobre o jornal. Segundo Henfil, o jornal foi fundamental tanto para o refinamento do perfil dos Fradins como para a concretização do projeto de compor uma publicação onde pudesse expor seus desenhos livres das restrições editoriais ou de espaço:

Comecei a fazer os fradinhos no Pasquim dentro de outro esquema ... Então começou com o encontro direto entre os dois e cada vez mais sério e eu não fazia mais um negócio do qual eu não participava. ... Fazia essa briga e o negócio foi em frente, com um sucesso terrível. Virei nacional. ... Antes disso eu já tinha tentado vender a idéia dos fradinhos em vários lugares: em São Paulo, tentei vender para o Estadão, Editora Abril, Manchete, Fatos e Fotos, Jornal do Brasil. Esse pessoal achava que não dava pé. Foi a sorte porque se eu fizesse nesses lugares eu estava arrebentado. Eu tinha realmente de pegar um lugar novo, onde pudesse implantar um esquema novo. ${ }^{13}$ 
A partir da participação e do sucesso alcançado no Pasquim, Henfil levou adiante a Revista Fradim, lançada em 1973 e, segundo Souza (1999, p.245), "uma das mais longevas experiências de publicações autorais de história em quadrinhos no Brasil". A publicação da revista se deu em cinco ciclos: "o almanaque (1971); do n. 2 ao n. 6 (de setembro de 1973 a fevereiro de 1974); do n. 7 ao n. 22 (de março de 1976 a setembro de 1977); do n. 23 ao n. 24 (entre março e julho de 1978) e, finalmente, do n. 25 ao n. 31 (de maio a dezembro de 1980)" (ibidem).

A distinção entre o conteúdo apresentado no Pasquim e o da revista está no aprofundamento das discussões sobre os problemas nacionais. Enquanto no jornal as histórias abordavam questões cotidianas relacionadas, sobretudo, ao âmbito dos costumes, na revista temáticas mais amplas trazidas à tona pelos movimentos sociais (relações de poder entre gêneros, transição política, anistia, homossexualidade, o movimento estudantil, entre outros ${ }^{14}$ ) foram tratadas com maior apuro sempre articuladas à questão do autoritarismo cuja representação na revista transcende o âmbito político, compreendendo outros aspectos da vida social. Paralelamente, a revista se configurou num respiradouro para os Fradins, que vinham perdendo seu dinamismo por causa da censura, configurando-se, desse modo, vital para a preservação dos dois personagens.

Quando o Fradim saiu do Pasquim e veio para sua própria revista é que muita coisa mudou. Descobri que aqui ele tinha dezenas de páginas para trabalhar. E vi então que, pelo fato de ter uma página no Pasquim, o Fradim tinha que dar o recado rápido. Era mais um Cartum, piadinha, chiste, que uma historinha em quadrinhos. E não havia tempo (espaço) para ele mostrar, quando relaxado, sua personalidade inteira. Era como se ele estivesse ali só para gravar um quadro no Fantástico. Tanto que vocês (nem eu) não sabem onde ele mora, o que come, qual a classe social e outras informações que no Zeferino abundam (ui!). Na revista ele tinha agora tempo (espaço) para deixar passar as informações e poderia inclusive dar umas vagabundadas que gerariam situações menos comprometidas com a gag final. E, podem notar, o superior da ordem apareceu e determinou mais onde vive o baixim. ... Observem que ele não faz mais o fim da gag. Ele está atuando como provocador das situações. É a reação das pessoas que é o final. ${ }^{15}$

A interrupção da publicação entre o número 6 e 7 e do número 24 ao 25 ocorreu em virtude do resultado frustrante que o constante exercício de autocensura exerceu sobre seu trabalho. Este processo de auto-regulação foi responsável ainda pela ausência dos Fradins em várias edições, como nos números 21 e 23. Apesar de a revista estar 
isenta de censura prévia, o temor de réplicas dirigidas aos outros jornais em que participava, assim como por uma questão de sobrevivência pessoal e da revista, o fez reforçar o mecanismo mediador indireto que foi a autocensura. Entre a castração ou a suspensão, a segunda alternativa foi adotada como recurso mais apropriado àquela situação que fugia ao seu controle,

Meu plano agora é só trabalhar com liberdade de criação e por isso decidi fazer a revolução completa: paro também com a revista do Fradim a partir do número 6. $\mathrm{Eu}$ vinha fazendo a revista com tremenda autocensura para evitar que recolhessem ela na banca e aí o Pasquim falisse junto. Não me dava nenhum prazer fazer, pois o que eu conseguia era apenas repetir o que já tinha feito antes e na base da água morna. Chega de brincar com minhas criações. ${ }^{16}$

Só pra verdade ficar completa: muitas vezes eu inicio a criação do fradim e tenho que me reprimir. Se publico aquilo eles fecham a revista, a Editora Codecri e quem sabe até a imprensa toda. Juro! ... Talvez, olhaí, talvez seja por isso que o parto seja tão doloroso assim. Poderia, como toda criação, ser um parto doloroso, mas normal. Como tenho que me preocupar com o cordão umbilical, pra ver se ele não está enrolado no pescoço, é sempre cesariana... ${ }^{17}$

Direcionando a análise para o código lingüístico dos Fradins sobressai-se o recurso à atmosfera verbal específica das brincadeiras e jogos infantis dos quais Henfil fez parte na periferia de Belo Horizonte, com uso frequiente de diminutivos (tadim, Fradim, Baixim, etc.). Através das imagens cômicas e da utilização de um vocabulário que mescla aspectos infantis com termos populares, o cartunista realizou a recriação de valores e práticas socioculturais colhidos e partilhados no cotidiano do senso comum de forma que estes perderam o caráter nonsensual, absurdo e banal, por assim dizer.

O emprego desse vocabulário de "chão de feira" (Bakhtin, 1996), impregnado de liberdade e franqueza, gera uma familiarização que, conforme Bakhtin, corresponde a uma categoria da cosmovisão carnavalesca. Essa familiaridade revoga o "sistema hierárquico e todas formas conexas de medo, reverência, devoção, etiqueta, etc., ou seja, tudo o que é determinado pela desigualdade (inclusive etária) entre os homens" (Bakhtin, 2002, p.123). Ao mesmo tempo em que está relacionada à profanação, outra categoria carnavalesca ${ }^{18}$.

Contudo, contrariando seus anseios, isso não garantiu a popularização dos seus desenhos. Ao serem apropriados pela linguagem gráfica, tornando-se registros impressos, ganharam ressonância e passaram a fazer parte de um jogo de sentidos metafóricos partilhado pela classe média intelectualizada ${ }^{19}$ adquirindo novos usos e significados simbólicos, compondo uma espécie de "linguagem do pê, que só nós 
entendemos e só nós percebemos a gravidade e qualidade" ${ }^{20}$. Para Henfil, a restrição do seu público estava associada basicamente aos problemas socioeconômicos do país, à concorrência desleal estabelecida com os quadrinhos estrangeiros, cujos preços eram bem menores que os quadrinhos nacionais, e com outros meios de comunicação de massa como a televisão que durante o regime militar aumentou significativamente seu alcance social.

A exposição e o deslocamento do universo primitivo infantil para o ambiente urbano do público classe média que o Pasquim almejava alcançar gerou o impacto dos Fradins sobre o público leitor. Os leitores do Pasquim caracterizavam-se pela busca de propostas alternativas no interior dos meios de comunicação, postando-se de forma aberta para inovações sejam estas lingüísticas, temáticas ou gráficas. Isso justifica, de certa forma, o aceno positivo desses leitores para os Fradins.

No que tange ao código lingüístico empregado nos Fradins, é importante assinalar o uso freqüente de onomatopéias para driblar a ausência de sons e movimentos e para a reprodução de tudo aquilo referente ao real que encontrasse dificuldades para definir-se de forma sucinta e precisa.

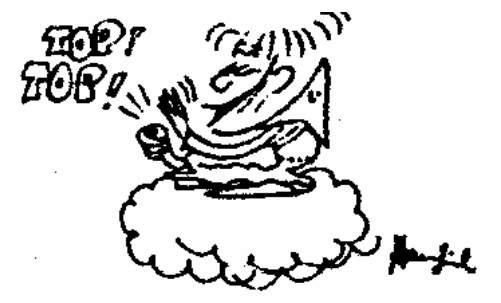

Destaca-se a apropriação do popular gesto de bater com a mão direita espalmada sobre a mão esquerda fechada em círculo, acompanhada da onomatopéia TOP! TOP! marca registrada do Baixim.

Figura 02 - Fonte: revista Fradim

Associado à extrema concisão dos traços, esta serviu tanto para expressar o sadismo do Baixim como para realçar os momentos em que, através do hiperbolismo e do rebaixamento, se colocavam em xeque determinadas práticas e valores sociais.

Outras formas de emprego das práticas populares por parte do Baixim são as manifestações gestuais (tirar meleca do nariz ou fazer gestos obscenos), além da quebra das convenções verbais (utilização de palavrões, palavreado grosseiro, injúrias e imprecações).

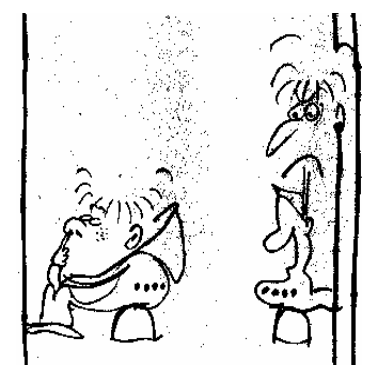

Figura 03 - Fonte: jornal Pasquim 
Conforme Henfil, tais expressões gestuais e verbais constituíram uma forma de "linguagem cifrada empregada para desacatar as otoridades". Desse modo, falava-se em "rabo, meleca e peido para insinuar o que quem já sabe, entende, e quem não sabe, continua sem entender" ${ }^{21}$. Junto a tais formas de agressões indiretas vinham as referências jocosas ao alto celestial e ao baixo corporal, a superação da hierarquia materna e religiosa, a ruptura dos padrões éticos e o recurso constante a jogos de adivinhas, como na tira abaixo:
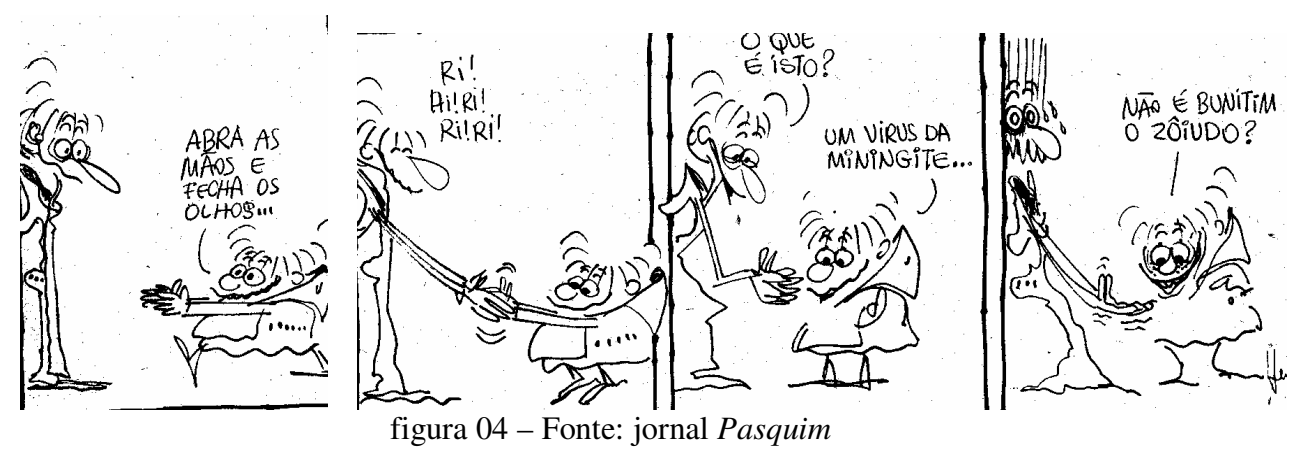

Dois aspectos importantes resultaram dessa ligação com o cotidiano e com o informal: primeiro, o surgimento de um vocabulário dinâmico e próprio capaz de comunicar uma visão invertida do real; e, segundo, o estabelecimento daquilo que ele caracterizava como "um pacto com o leitor", fundamental para dar continuidade aos seus desenhos (Souza, 1984).

No exame dos temas que são abordados pelos Fradins destacam-se as alusões às questões relacionadas à sexualidade (masculina e feminina) e a homossexualidade (masculina) associada à marcação moral implementada pela ditadura militar e referendada pelos grupos conservadores representantes da sociedade civil. Amalgamada ao discurso político do regime militar, a retórica conservadora propalada no interior da sociedade civil desde o limiar do golpe encontrou amparo legal no Decreto-lei n. 1.077, de 26 de janeiro de 1970, para se consolidar. Esse decreto-lei incorporou novos elementos à censura prévia sobre diversões públicas, já existente desde 1946, sob o argumento de garantir a "proteção" da instituição familiar de "publicações obscenas" realizadas por revistas, canais de televisão que: 
executam programas contrários à moral e aos bons costumes" e "livros que ofendem frontalmente a moral comum", pois conforme sua apreciação: "tais publicações e exteriorizações estimulam a licença, insinuam o amor livre e ameaçam destruir os valores morais da sociedade brasileira" assim como "o emprego desses meios de comunicação obedece a um plano subversivo que põe em risco a segurança nacional. ${ }^{22}$

À Divisão de Censura de Diversões Públicas (DCDP) coube o rigoroso controle sobre os temas ligados às práticas comportamentais ou morais e, de forma sigilosa, a qualquer tipo de referência crítica à política. A assimilação deste controle moral foi algo patente entre a sociedade civil, expresso através de cartas encaminhadas ao DCDP dirigidas a senadores, ministros, superintendentes regionais, diretores, entre outros importantes cargos do regime militar.

Avultam ainda as menções que ridicularizam normas e restrições políticas correntes, bem como as emergentes opções ideológicas alternativas que, por sua vez, buscaram compor um contraponto às premissas da esquerda.

Dentre outros temas abordados destaco as referências aos ritos sociais (aniversário, casamento, Natal, Páscoa) e a ênfase através das atitudes sádicas do Baixim no questionamento do caráter cristão, de confraternização ou de harmonia que está subjacente nas referências discursivas oficiais sobre estes momentos. Apresento duas estórias ${ }^{23}$ cuja abordagem dada aos temas referidos busca ora evidenciar as contradições inerentes ao discurso oponente, ora carnavalizar seus pressupostos centrais; nestas coube ao Cumprido a incorporação dos dois tipos adversos de posturas ideológicas.

Na primeira, o porte dos óculos, além do próprio conteúdo discursivo, reforça a representação da condição didática e convencional do Cumprido. Na segunda, o reforço imagético está na forma de sentar adotada pelo Cumprido, própria da incorporação por parte da contracultura de referências espirituais e religiosas do orientalismo:
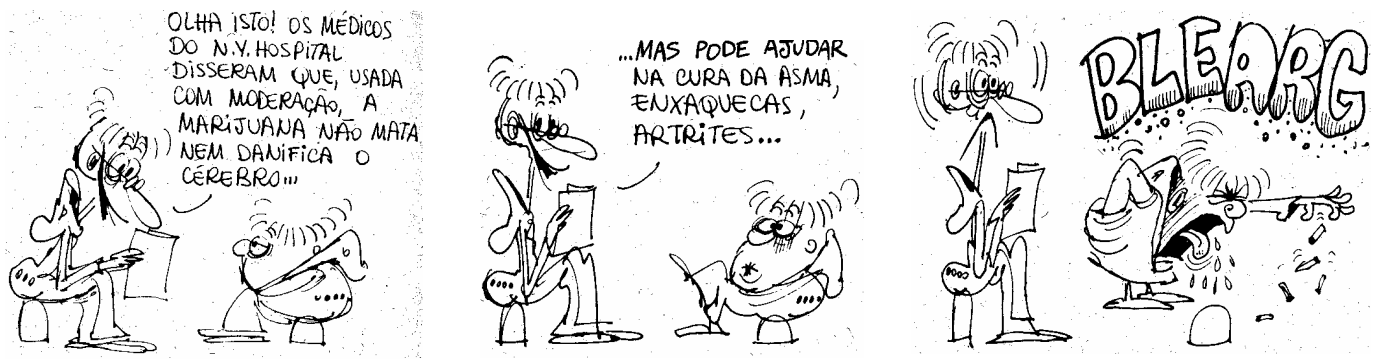

Figura 05 - fonte: jornal Pasquim 


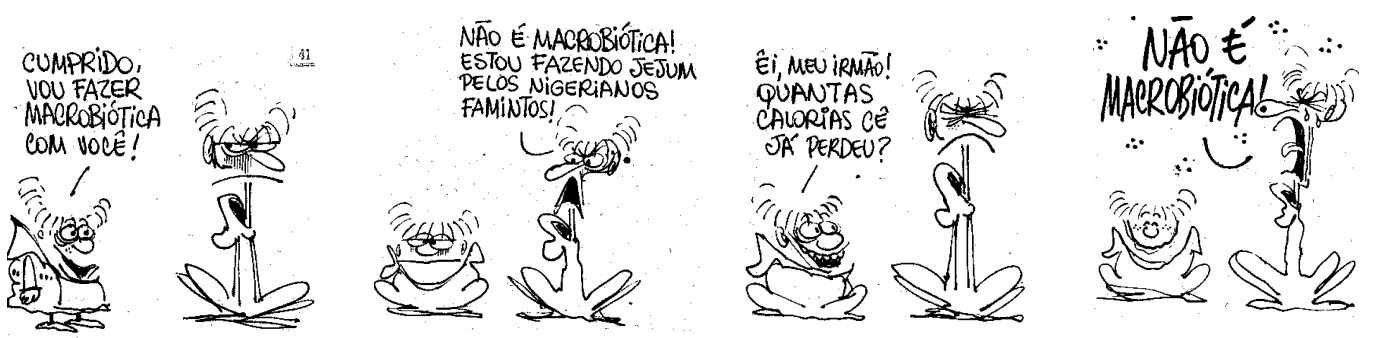

Figura 06 - fonte: jornal Pasquim

Finalmente, observei uma ênfase maior às alusões às retóricas cristã e familiar (irmandade, benevolência, devoção, otimismo, afetividade), em geral associadas ao "baixo material e corporal" e ao rebaixamento do divino e dos ícones (mãe, pai) e valores familiares. Normalmente, nas estórias em que há a presença da divindade, sua postura comunga com as ações praticadas pelo Baixim, reforçando esse processo de desmitificação. O mesmo ocorre nas estórias em que são exploradas as referências ligadas aos valores familiares, sobretudo a maternidade.

Apresento mais duas estórias, ambas retiradas do livro póstumo "A Volta do Fradim: uma antologia histórica" (Cosenza 2003), que serão utilizadas para arrematar esse tópico. Acredito que a presença da mãe do Baixim na segunda estória, partilhando da gag final, corrobora com minhas assertivas sobre a desmitificação dos ícones religiosos e familiares:

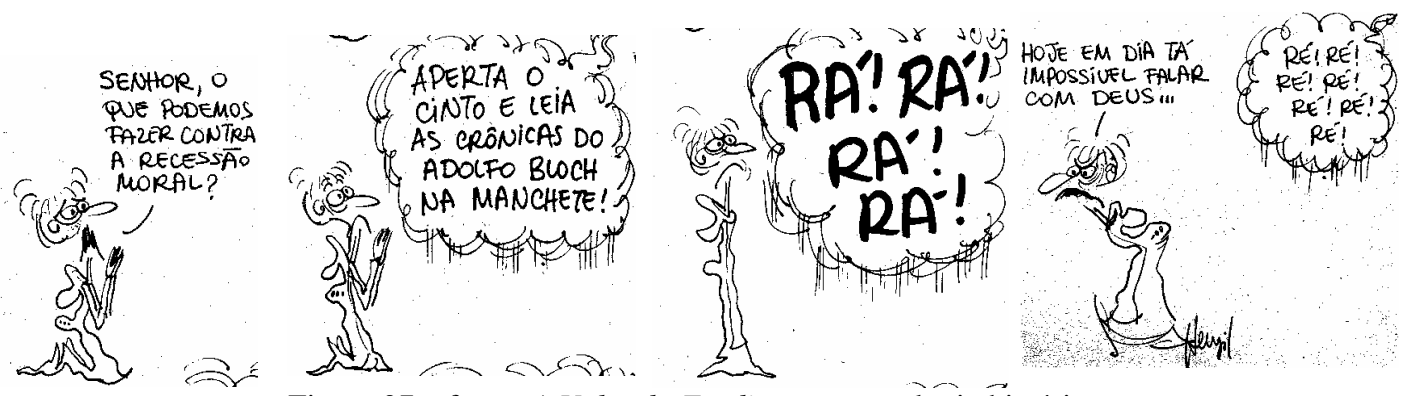

Figura 07 - fonte: A Volta do Fradim: uma antologia histórica 


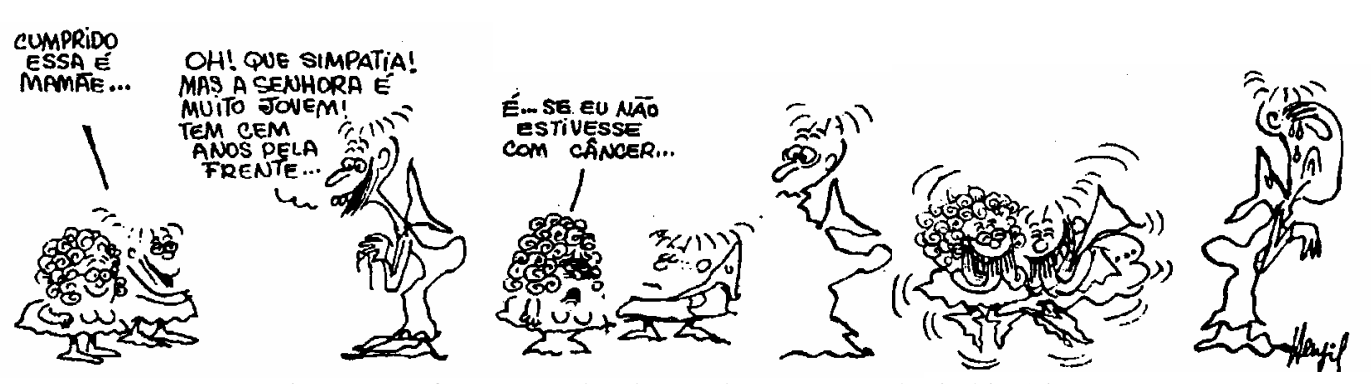

Figura 08 - fonte: A Volta do Fradim: uma antologia histórica

A abordagem destas especificidades temáticas, no cenário político dos anos 1970, fragmentou tanto os discursos tradicionais em favor da família, dos costumes, da religião, um dos pilares em que se ancorou o regime militar com o apoio dos estratos conservadores da sociedade brasileira, como práticas e hábitos ligados à contracultura. Ao mesmo tempo, as estórias dos Fradins buscavam expressar as contradições em que vivia submersa a classe média, cindida entre a ardilosa euforia promovida pelo "milagre econômico" e a barbárie praticada dentro e fora dos porões do regime. Vivia-se "uma alegoria do real" e nessa condição de predominância do absurdo é que o humor instaura uma possibilidade de sobrevivência existencial ... (Seixas, 1980, p.88-92).

Como já se sabe, a radicalização do regime veio com a promulgação do AI-5 que ofertou as condições para a ordenação da censura em diversos âmbitos da sociedade brasileira. Paralelamente a este processo de radicalização ocorreu a definição de um perfil sádico para os Fradins, especificamente o alto teor de agressividade e anarquismo que se tornaria característica distintiva da personalidade do Baixim. Segundo Henfil, "nós estávamos todos perdidos, o AI-5 vindo, censura prévia vindo e aquela coisa... e ele era catártico! Ele conseguia respirar e cantar em plena tempestade" (Souza, 1984, p.38). Fechadas as brechas por onde passavam as críticas ao novo panorama político institucional, buscaram-se alternativas para, por um lado, confrontar as novas formas de repressão, voltando-se desta vez para aquelas que envolviam os costumes sociais, e, por outro, provocar um efeito catártico transformando-os numa forma de exorcização dos valores da classe média que apoiava o regime. Inspirado pelas repressões vivenciadas em seu círculo familiar católico, inicia-se a partir de então o mergulho crítico no universo dos costumes burgueses, dando a partida para:

uma liberação, uma linguagem que não era permitida, então o Fradim tirou meleca, e naquela época isso era subversivo $^{24} \ldots$ O Baixinho anarquiza, ridiculariza e agride as falsidades e as hipocrisias da sociedade em que vivo. Ele 
é toda uma negação da religião do terror, na qual tudo é pecado. Minha política é simples: poesia não, sadismo sim. (Henfil, apud Moraes, 1996, p.104)

Esta crítica dos costumes coincidiu com as demandas da classe média intelectualizada por novas e diversificadas formas de manifestação do sentimento de oposição ao regime militar. No impreciso ambiente autoritário da ditadura militar "com regras cambiantes, e móveis as divisas entre o proibido e o permitido" (Almeida \& Weis, p.327), e em conjunto com as recorrentes referências aos valores familiares e católicos, tais personagens ganharam significados variados de oposição. Tratava-se, assim, de uma forma fluida de resistência partilhada com outras práticas de oposição, também fluidas, vigentes naquele momento, tais como:

... assinar manifestos, participar de assembléias, criar músicas, romances, filmes ou peças de teatro; emprestar a casa para reuniões políticas, guardar ou distribuir panfletos de organizações ilegais, abrigar um militante de passagem; fazer chegar à imprensa denúncias de tortura, participar de centros acadêmicos ou associações profissionais, e assim por diante. (ibidem)

É óbvio que nem sempre Henfil obteve sucesso na resposta do leitor às críticas estabelecidas pelos personagens. Em alguns momentos, ele se mostrou consciente dos limites entre a intenção do autor e a liberdade interpretativa: "você pode criar um personagem para defender determinada idéia, mas como você precisa da parceria do leitor pode o veneno virar remédio e vice-versa" (Souza, 1984, p.15); entretanto, isto não evitou que travasse intensas brigas com o leitor por não admitir o tipo de apropriação que se efetuava.

A livre apropriação por parte do leitor o levou a suspender pela primeira vez a publicação de estórias com o Baixim $^{25}$ de modo que despertasse o leitor para o objetivo político de sua produção humorística. Contudo, apesar da imprevisibilidade da ação leitora, em nenhum momento encontrei referências vindas de leitores que associassem diretamente Henfil, ou a sua produção humorística, a uma prática não engajada politicamente (Chauí, 1986; Silva, 2000). Colocando-se tais aspectos em relevo percebe-se que não se trataram de meras representações artísticas da realidade, mas, tal qual citado por Bakhtin quando se referindo ao carnaval no medievo, se situaram "nas fronteiras entre a arte e a vida. ... é a própria vida apresentada com os elementos característicos da representação" (Bakhtin, 1996, p.6). 
Para a abordagem desse campo temático, com ênfase sobre suas contradições e incongruências, Henfil recorreu a procedimentos próprios daquilo que Bakhtin (ibidem) definiu como "realismo grotesco", onde prevalece o exagero, o rebaixamento e a degradação, proporcionando ao leitor um distanciamento que não só desmistifica como materializa tudo o que possa ter um caráter "sublime", aproximando-o do que é humano e universal.

Compreendo que tal aproximação garante ao humor henfiliano um valor positivo e regenerador, pois colabora para o entendimento de uma perspectiva diversa da dominante. Neste sentido, "permite olhar o universo com novos olhos, compreender até que ponto é relativo tudo o que existe e, portanto, compreender a possibilidade de uma ordem totalmente diferente do mundo" (ibidem, p.30). Trata-se, assim, de um humor que amortalha o mito e regenera o humano, tornando-se ao mesmo tempo negação e afirmação de um ideário alternativo ao existente. Como contraponto à exacerbação dos valores morais cristãos, apresentado como forma plausível de solapar a subversão política, Henfil apresentou a indisciplinada postura crítica do Baixim que com suas insinuações indagadoras discutiu a inexistência de referências éticas neste projeto moralizador e a desumanização crescente a que esta retórica conduziu.

\section{REFERÊNCIAS BIBLIOGRÁFICAS:}

ALMEIDA, Maria Hermínia Brandão Tavares de e WEIS, Luiz, Carro-zero e pau-dearara: o cotidiano da oposição de classe média ao regime militar. In SCHWARCZ, Lilia K. Moritz, (org.) História da vida privada no Brasil: contrastes da intimidade contemporânea. São Paulo: Companhia das Letras, 2000, pp. 319-409.

BAKHTIN, M. A Cultura Popular na Idade Média e no Renascimento. O contexto de François Rabelais. São Paulo/Brasília: Hucitec/UNB, 1996.

. Problemas da Poética de Dostoievsky. Rio de Janeiro: Forense Universitária. 2002.

CHAUÍ, Marilena. Conformismo e Resistência. São Paulo: Brasiliense, 1986

COSENZA, Ivan (Org.). A Volta do Fradim: uma antologia histórica: charges. 5.ed. São Paulo: Geração Editorial, 2003. 
FICO, Carlos. Além do Golpe: versões e controvérsias sobre 1964 e a ditadura militar. Rio de Janeiro: Record, 2004.

HOLLANDA, H. B. Impressões de Viagem: CPC, Vanguarda e Desbunde: 1960/1970. São Paulo: Brasiliense, 1992.

MORAES, Denis. O Rebelde do Traço: a vida de Henfil. Rio de Janeiro: José Olympio, 1996.

Rego, N. P. Pasquim: gargalhantes pelejas. Rio de Janeiro: Relume-Dumará/Prefeitura, 1996.

REZENDE, C. B. Os Limites da Sociabilidade: "Cariocas" e "Nordestinos" na Feira de São Cristóvão. Revista Estudos Históricos. n.28, 2001.

SCHWARCZ, Lilia M. (Org.). História da Vida Privada no Brasil: contrastes da intimidade contemporânea. São Paulo: Cia. das Letras, 1998.

SEIXAS, Rozeny Silva. Zeferino: Henfil \& Humor na revista Fradim. Rio de Janeiro, 1980. Dissertação de Mestrado em Comunicação - Escola de Comunicação da UFRJ.

SILVA, Marcos da. Rir das Ditaduras: os dentes de Henfil (ensaios sobre Fradim 1971/1980). São Paulo, 2000. Tese de Livre Docência em Metodologia (História) FFLCH/USP.

SOUZA, Mauricio Maia. Henfil e a Censura: o papel dos jornalistas. São Paulo, 1999.

Dissertação de Mestrado - ECA: USP.

SOUZA, Tarik de. Como se faz humor político. Depoimento a Tarik de Souza. Petrópolis: Vozes, 1984.

PIRES, Maria da Conceição Francisca. Culture and politics in Henfil's cartoons. História, São Paulo, v. 25, n. 2, p. 94-114, 2006.

\begin{abstract}
The article presents a incursion for the discursive universe of the controversial characters "Fradins", created by the cartunist Henfil. The intention is pointing out, on one hand, the curbed politics and customs construction, and, on the other hand, the religious elites obliging Christianity politics as well as the social simulacra. The studied case is not only about the critical devotion, but specifically about the devotion to the power. I defend the premise that, by means of grotesques and fantastic features, in irony and carnavalization scenario, Henfil has demystified the religious and political deities, replacing them with the doubt and placing them side by side with ridicule. In this way, the henfilianian mood represents a resistance effort, at the same time that contributes for the political fight against the military dictatorship.
\end{abstract}

Keywords: mood, politics, dictatorship 
Artigo recebido em 8/2006. Aprovado em 12/2006.

\section{NOTAS}

* Pesquisadora da Fundação Casa Rui Barbosa, Rio de Janeiro/RJ - Brasil.
1 O CPC foi um movimento cultural criado nos anos 1960 que contou com a participação de Ferreira
Gullar, Arnaldo Jabor, Cacá Diegues, entre outros, para a difusão de uma arte engajada, participante e
revolucionária voltada para a conscientização das "massas" e para o desenvolvimento de inovadoras propostas de pesquisas dirigidas ao campo artístico nacional.

${ }^{2}$ Consta que numa partida contra o Botafogo em que o Flamengo perdia de 1 X 0 foi jogado no campo, por um torcedor rubro-negro, um urubu com a bandeira do Flamengo amarrada a uma das patas. Sob forte impacto, a torcida começou a gritar: "É urubu!, É urubu!", e o placar do jogo virou para 3 X 1. Em outra ocasião numa visita ao Maracanã numa final entre Fluminense e Flamengo o General Médici afirmou torcer pelo Flamengo através da afirmativa "Sou urubu!". Mais referências a este respeito, ver Moraes, 1996.

${ }^{3}$ Entrevista ao Pasquim, em junho de 1973, publicada no Diário de um Cucaracha, Rio de Janeiro: Record, 1983.

${ }_{5}^{4}$ A primeira aparição foi em setembro de 1970, no número 64 do Pasquim.

5 A série tem início no número Jornal Pasquim 131, de 04 a 10/01/1972, com a apresentação feita pelo próprio Cabôco do seu cemitério particular.

${ }^{6}$ Estou me referindo ao seu núcleo inicial: Sérgio Cabral, Tarso de Castro, Millôr Fernandes, Jaguar, Ziraldo Alves Pinto, Sérgio Augusto, Fortuna, Claudius Ceccon, Luiz Carlos Maciel, Martha Alencar, Ivan Lessa.

7 Roberto Drumond: jornalista, diretor responsável pelo soerguimento da revista mineira Alterosa, fundada em 1939, pelo também jornalista Miranda Castro. Segundo relato reproduzido por Denis Moraes, foi Drumond quem cedeu a Henfil o trabalho de cartunista na revista após constatar sua inaptidão para a função de revisor na qual trabalhava, bem como sugeriu o uso do codinome "Henfil" para assinar os desenhos (Ver Moraes, 1996, p.52-4).

${ }^{8}$ Seção Fala, Leitor! Revista Fradim, n.18, p.47, 1977.

${ }^{9}$ Entrevista, Revista Fradim, n.21, p.18-9, 1977.

${ }^{10}$ Citado por Souza, 1999, p.212.

${ }^{11}$ Segundo Henfil, inúmeras vezes a doença foi utilizada como artifício para se esquivar das obrigações escolares ou para agredir rivais de turma com a garantia de não haver o revide, transformando a posse da doença num sinistro privilégio. Identifica-se nesse exercício cotidiano de rir de si como condição de sobrevivência e autoproteção a gestão da atitude de distanciamento, a meu ver marca indelével de seu trabalho, como forma de reconhecimento de suas próprias misérias e das particularidades do outro.

${ }^{12} \mathrm{Na}$ entrevista concedida à Tarik de Souza, Henfil cita os humoristas cuja influência foram cruciais para o seu trabalho: Millôr Fernandes, Stanislaw Ponte Preta, Borjalo, Carlos Estevão, Jaguar, Fortuna, Claudius, Ziraldo, além de Roland, que fazia ilustrações na revista Esso e Rafael, cujos desenhos saíam no Saturday Evening Post, na seção Post Scriptum (Souza, 1984, p.68).

${ }^{13}$ Entrevista, Revista Fradim, n.21, p.28-9, 1977.

${ }^{14}$ A esse respeito, ver Silva 2000.

${ }^{15}$ Seção Fala, Leitor! Revista Fradim, n.12, p.44-5, 1976.

${ }^{16}$ Cartas. Revista Fradim, n.25, p.42, 1980.

${ }^{17}$ Seção Fala, Leitor! Revista Fradim, n.24, p. 31-2, 1978.

${ }^{18}$ Conforme Bakhtin, a profanação é "formada pelos sacrilégios carnavalescos, por todo um sistema de descidas e aterrissagens carnavalescas, pelas indecências carnavalescas, relacionadas com a força produtora da terra e do corpo, e pelas paródias carnavalescas dos textos sagrados e sentenças bíblicas, etc." (ibidem).

19 Em concordância com a classificação de Almeida e Weis quando menciono "classe média intelectualizada", estou me referindo à "estudantes politicamente ativos, professores universitários, 


\section{CULTURA E POLÍTICA NOS QUADRINHOS DE HENFIL}

profissionais liberais (com formação superior), artistas, jornalistas publicitários, etc.”. Carro Zero e paude-arara: o cotidiano da oposição de classe média ao regime militar (in: Schwarcz, 1998, p.326).

${ }^{20}$ Cartas, revista Fradim, n.22, p.21,1977.

${ }^{21}$ Cartas, revista Fradim, n.30, p.24, 1980.

${ }^{22}$ Citado por Fico, 2004, p.390.

${ }^{23}$ Publicadas no Pasquim de 31 de dezembro de 1974 a 6 de janeiro de 1975; n.296, $1^{\circ}$ a 7 de março de 1975.

${ }_{25}^{24}$ Singular \& Plural, abril/79, p.26: "Quando o top-top era caso de polícia".

${ }^{25}$ Pasquim, n. 25, de 11 a 17/12/1969. A segunda morte do Baixim, dessa vez por atropelamento, ocorre também do Pasquim, no n. 33, de 5 a 11/02/1970. Outros personagens morreram com o mesmo intuito, como a Graúna, na Revista Fradim n.9 e 10, 1976. 